\title{
Titanium Dioxide Particle Type and Concentration Influence the Inflammatory Response in Caco-2 Cells
}

\author{
Saeko Tada-Oikawa ${ }^{1,2}$, Gaku Ichihara ${ }^{3}$, Hitomi Fukatsu ${ }^{1}$, Yuka Shimanuki ${ }^{1}$, Natsuki Tanaka ${ }^{1}$, \\ Eri Watanabe ${ }^{3}$, Yuka Suzuki ${ }^{2,+}{ }^{\text {, }}$, Masahiko Murakami ${ }^{2}$, Kiyora Izuoka ${ }^{2}$, Jie Chang ${ }^{2, \ddagger}$, \\ Wenting $\mathrm{Wu}^{2,8}$, Yoshiji Yamada ${ }^{4}$ and Sahoko Ichihara ${ }^{2,4, *}$ \\ 1 Department of Human Nutrition, School of Life Studies, Sugiyama Jogakuen University, \\ Nagoya 464-8662, Japan; t-saeko@sugiyama-u.ac.jp (S.T.-O.); fha12aa100@st.sugiyama-u.ac.jp (H.F.); \\ sya12aa057@st.sugiyama-u.ac.jp (Y.Sh.); tna12aa069@st.sugiyama-u.ac.jp (N.T.) \\ 2 Graduate School of Regional Innovation Studies, Mie University, Tsu 514-8507, Japan; \\ suzujohn@yahoo.co.jp (Y.Su.); 309111@m.mie-u.ac.jp (M.M.); izuoka@innov.mie-u.ac.jp (K.I.); \\ jchang@suda.edu.cn (J.C.); wendywu1206@163.com (W.W.) \\ 3 Department of Occupational and Environmental Health, Tokyo Univeristy of Science, Noda 278-8510, Japan; \\ gak@rs.tus.ac.jp (G.I.); eri.watanabe.0503@gmail.com (E.W.) \\ 4 Department of Human Genomics, Life Scinece Research Center, Mie University, Tsu 514-8507, Japan; \\ yamada@gene.mie-u.ac.jp \\ * Correspondence: saho@gene.mie-u.ac.jp; Tel.: +81-59-231-5389; Fax: +81-59-231-5388 \\ + Present address: Department of Cardiovascular Medicine, Graduate School of Medicine, Kyoto University, \\ Kyoto 606-8501, Japan. \\ $\ddagger$ Present address: School of Public Health, Medical College of Soochow University, Suzhou 215006, China. \\ Academic Editor: Michael Routledge \\ Received: 29 February 2016; Accepted: 11 April 2016; Published: 16 April 2016
}

\begin{abstract}
Titanium dioxide $\left(\mathrm{TiO}_{2}\right)$ nanoparticles are widely used in cosmetics, sunscreens, biomedicine, and food products. When used as a food additive, $\mathrm{TiO}_{2}$ nanoparticles are used in significant amounts as white food-coloring agents. However, the effects of $\mathrm{TiO}_{2}$ nanoparticles on the gastrointestinal tract remain unclear. The present study was designed to determine the effects of five $\mathrm{TiO}_{2}$ particles of different crystal structures and sizes in human epithelial colorectal adenocarcinoma (Caco-2) cells and THP-1 monocyte-derived macrophages. Twenty-four-hour exposure to anatase (primary particle size: 50 and $100 \mathrm{~nm}$ ) and rutile $(50 \mathrm{~nm}) \mathrm{TiO}_{2}$ particles reduced cellular viability in a dose-dependent manner in THP-1 macrophages, but in not Caco-2 cells. However, 72-h exposure of Caco- 2 cells to anatase $(50 \mathrm{~nm}) \mathrm{TiO}_{2}$ particles reduced cellular viability in a dose-dependent manner. The highest dose $(50 \mu \mathrm{g} / \mathrm{mL})$ of anatase $(100 \mathrm{~nm})$, rutile $(50 \mathrm{~nm})$, and $\mathrm{P}_{2} 5 \mathrm{TiO}_{2}$ particles also reduced cellular viability in Caco-2 cells. The production of reactive oxygen species tended to increase in both types of cells, irrespective of the type of $\mathrm{TiO}_{2}$ particle. Exposure of THP-1 macrophages to $50 \mu \mathrm{g} / \mathrm{mL}$ of anatase $(50 \mathrm{~nm}) \mathrm{TiO}_{2}$ particles increased interleukin (IL)- $1 \beta$ expression level, and exposure of Caco- 2 cells to $50 \mu \mathrm{g} / \mathrm{mL}$ of anatase $(50 \mathrm{~nm}) \mathrm{TiO}_{2}$ particles also increased IL- 8 expression. The results indicated that anatase $\mathrm{TiO}_{2}$ nanoparticles induced inflammatory responses compared with other $\mathrm{TiO}_{2}$ particles. Further studies are required to determine the in vivo relevance of these findings to avoid the hazards of ingested particles.
\end{abstract}

Keywords: nanoparticles; titanium dioxide; food additive; intestinal epithelium; macrophage; inflammation; reactive oxygen species

\section{Introduction}

Engineered nanoparticles (NPs), defined as particles with diameters of less than $100 \mathrm{~nm}$, exhibit new physicochemical features at the nanoscale, such as large surface area, altered electronic properties, 
reactivity, and surface derivatization [1,2]. With the development of nanotechnology, an increasing number of nanoproducts are presently available in electronics, cosmetics, drug delivery systems, and food products [3,4]. Among them, titanium dioxide $\left(\mathrm{TiO}_{2}\right) \mathrm{NPs}$ are manufactured in large quantities and commercialized for various uses based on their high stability, photocatalytic effects, and whitening [5]. $\mathrm{TiO}_{2} \mathrm{NPs}$ are typically synthesized in three different crystalline structures; anatase, rutile, or brookite [6], and the first two types are mainly used as industrial materials. Because of their low degree of toxicity and physicochemical properties, $\mathrm{TiO}_{2} \mathrm{NPs}$ are widely used in a broad range of products, such as toothpaste, sunscreen, cosmetics, pharmaceuticals, and nanomedical reagents [7-9]. The use of engineered NPs in the food industry has been growing rapidly, based on added benefits, such as improved taste and texture, prolonged shelf life, and enhanced nutritional qualities [10].

Recent studies have demonstrated that $\mathrm{TiO}_{2} \mathrm{NPs}$ are also used as food color additives and flavor enhancers [4]. Especially, high Ti amounts, e.g., 0.01-1 mg Ti per unit have been found in candies, sweets, and chewing-gums [11]. The study of Weir et al. [11] in the U.S. concluded that approximately $36 \%$ of $\mathrm{TiO}_{2}$ particles in food products were nanosized and indicated that the average exposure level to $\mathrm{TiO}_{2}$ particles was estimated at $1-2 \mathrm{mg} \mathrm{TiO} / 2 / \mathrm{kg}$ body weight (BW)/day for children and approximately $0.2-0.7 \mathrm{mg} \mathrm{TiO}_{2} / \mathrm{kg} \mathrm{BW} /$ day for other consumers. Moreover, another study demonstrated that in six brands of sugar-coated chewing gum, $>93 \%$ of $\mathrm{TiO}_{2}$ particles were smaller than $200 \mathrm{~nm}$ and $18 \%-44 \%$ of $\mathrm{TiO}_{2}$ particles were smaller than $100 \mathrm{~nm}$, and around $95 \%$ of the nano- $\mathrm{TiO}_{2}$ particles were swallowed when a person chewed the gum [12]. While oral exposure to $\mathrm{TiO}_{2} \mathrm{NPs}$ seems unavoidable, consumers have raised concern on the introduction of nanotechnology in the food without any safety information. Therefore, it is important to investigate the effects of $\mathrm{TiO}_{2} \mathrm{NPs}$ on the gastrointestinal tract for safety assessment of $\mathrm{TiO}_{2} \mathrm{NPs}$. However, the majority of studies on $\mathrm{TiO}_{2} \mathrm{NPs}$ toxicity investigated the risks associated with inhalation [13] and only a few data are available on the toxicity and cellular responses of intestinal cells to exposure to $\mathrm{TiO}_{2} \mathrm{NPs}$. The purpose of the present study was to determine the effects of exposure to $\mathrm{TiO}_{2}$ particles of different crystal structure and size in human epithelial colorectal adenocarcinoma (Caco-2) cells and THP-1 monocyte-derived macrophages.

\section{Results}

\subsection{Characterization of Suspensions of Titanium Dioxide $\left(\mathrm{TiO}_{2}\right)$ Particles}

We selected $50 \mathrm{~nm}$ of anatase and rutile $\mathrm{TiO}_{2}$ particles as the nano-sized $\mathrm{TiO}_{2}$ particles and $100 \mathrm{~nm}$ of anatase and $250 \mathrm{~nm}$ of rutile $\mathrm{TiO}_{2}$ particles as the large-sized $\mathrm{TiO}_{2}$ particles. We also used $\mathrm{TiO}_{2} \mathrm{NPs}$ (Degussa, $\mathrm{P} 25 ; 21 \mathrm{~nm}$ ), which are the standard materials in the field of photocatalytic reactions, contain anatase and rutile phases in a ratio of about 4:1 w/w.

Nano-sized $\mathrm{TiO}_{2}$ particles were dispersed in the each culture medium of THP-1 and Caco- 2 cells. The intensity-weighted hydrodynamic average diameter ( $z$-average) of dispersed NPs was measured by the dynamic light scattering (DLS) technology, as described previously [14,15]. Table 1 shows the mean hydrodynamic diameters, polydispersity index (PdI), and $\zeta$ potential of dispersed $\mathrm{TiO}_{2}$ particles in each medium. The DLS data of $\mathrm{TiO}_{2}$ NPs indicated that the mean hydrodynamic diameter was $>150 \mathrm{~nm}$ and confirmed the presence of nano-sized particles in the medium (Figure 1). The $\zeta$ potential of all particles in both cell media ranged from -11 to $-14 \mathrm{mV}$ (Table 1). No association between size or crystal structures and electrophoretic mobility of the particles was found. 
A

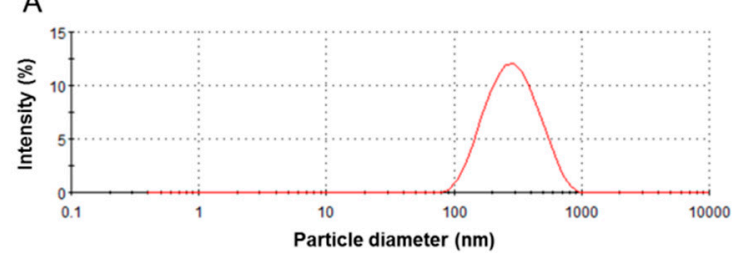

B

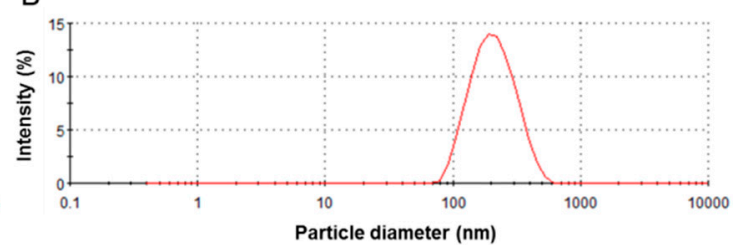

C

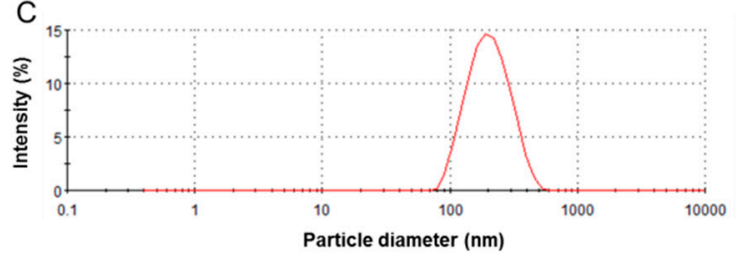

Figure 1. Histogram of particle size measured by dynamic light scattering technology. (A) anatase $(50 \mathrm{~nm})$; (B) rutile $(50 \mathrm{~nm})$; and $(\mathbf{C}) \mathrm{P} 25(21 \mathrm{~nm})$ titanium dioxide nanoparticles $\left(\mathrm{TiO}_{2} \mathrm{NPs}\right)$ suspensions were dispersed using a sonicator (model 450, Branson Sonifier, Danbury, CT, USA) set at 100 watt (W), $80 \%$ pulse mode, for $15 \mathrm{~min}$.

Table 1. Characterization of $\mathrm{TiO}_{2}$ particles.

\begin{tabular}{|c|c|c|c|c|c|}
\hline Particles & $\begin{array}{c}\text { Primary } \\
\text { Diameter }(\mathrm{nm})\end{array}$ & Medium & $\begin{array}{c}\text { Hydrodynamic } \\
\text { Size (nm) }\end{array}$ & PdI & $\begin{array}{l}\zeta \text { Potential } \\
(\mathrm{mV})\end{array}$ \\
\hline \multirow{2}{*}{ A50 } & \multirow{2}{*}{50} & RPMI1640 (10\% FBS) & $205.30 \pm 4.88$ & $0.319 \pm 0.007$ & $-11.86 \pm 1.47$ \\
\hline & & DMEM (10\% FBS) & $227.78 \pm 3.62$ & $0.291 \pm 0.012$ & $-11.31 \pm 0.39$ \\
\hline \multirow{2}{*}{ A100 } & \multirow{2}{*}{100} & RPMI1640 (10\% FBS) & $262.10 \pm 4.66$ & $0.191 \pm 0.026$ & $-11.66 \pm 1.38$ \\
\hline & & DMEM (10\% FBS) & $253.40 \pm 4.11$ & $0.171 \pm 0.010$ & $-11.84 \pm 1.74$ \\
\hline \multirow{2}{*}{$\mathrm{R} 50$} & \multirow{2}{*}{50} & RPMI1640 (10\% FBS) & $193.28 \pm 1.37$ & $0.120 \pm 0.032$ & $-13.15 \pm 1.05$ \\
\hline & & DMEM (10\% FBS) & $194.20 \pm 2.14$ & $0.123 \pm 0.011$ & $-11.66 \pm 0.64$ \\
\hline \multirow{2}{*}{$\mathrm{R} 250$} & \multirow{2}{*}{250} & RPMI1640 (10\% FBS) & $439.13 \pm 8.665$ & $0.163 \pm 0.010$ & $-12.18 \pm 0.59$ \\
\hline & & DMEM (10\% FBS) & $441.28 \pm 6.65$ & $0.155 \pm 0.025$ & $-11.75 \pm 1.14$ \\
\hline \multirow{2}{*}{ P25 } & \multirow[b]{2}{*}{21} & RPMI1640 (10\% FBS) & $181.55 \pm 1.10$ & $0.153 \pm 0.014$ & $-13.10 \pm 1.57$ \\
\hline & & DMEM (10\% FBS) & $193.85 \pm 1.86$ & $0.142 \pm 0.008$ & $-12.26 \pm 1.11$ \\
\hline
\end{tabular}

Data are mean \pm SD of three or four independent experiments. PdI: polydispersity index; RPMI: roswell park memorial institute; DMEM: dulbecco's modified eagle's medium; FBS: fetal bovine serum; $\mathrm{TiO}_{2}$ : titanium dioxide.

\subsection{Effects of Exposure on Cell Viability}

THP- 1 macrophages and Caco-2 cells were exposed to $\mathrm{TiO}_{2}$ particles at a concentration ranging from 1 to $50 \mu \mathrm{g} / \mathrm{mL}$ for 24 or $72 \mathrm{~h}$.

Cell viability of THP- 1 macrophages decreased after exposure to 25 and $50 \mu \mathrm{g} / \mathrm{mL}$ of anatase $\mathrm{TiO}_{2}$ particles of primary diameter of $50 \mathrm{~nm}$ (A50) (Figure 2A) and $10-50 \mu \mathrm{g} / \mathrm{mL}$ of anatase $\mathrm{TiO}_{2}$ particles of primary diameter of $100 \mathrm{~nm}$ (A100) (Figure 2B). Exposure to 25 and $50 \mu \mathrm{g} / \mathrm{mL}$ of rutile $\mathrm{TiO}_{2}$ particles of primary diameter of $50 \mathrm{~nm}$ (R50) also reduced the viability of THP-1 macrophages (Figure 2C), but no changes were noted in cells exposed to rutile $\mathrm{TiO}_{2}$ particles with primary diameter of $250 \mathrm{~nm}$ (R250) and P25 (Figure 2D,E). Figure 3 shows changes of viability of Caco-2 cells exposed to various $\mathrm{TiO}_{2}$ particles. No change in Caco-2 cell viability was evident following 24 h-exposure to all types of $\mathrm{TiO}_{2}$ particles (Figure 3A-E), while 72-h exposure to A50 $(10,25,50 \mu \mathrm{g} / \mathrm{mL}$, Figure 4A), A100 $(50 \mu \mathrm{g} / \mathrm{mL}$, Figure 4B), R50 (50 $\mu \mathrm{g} / \mathrm{mL}$, Figure 3C), and P25 (25, $50 \mu \mathrm{g} / \mathrm{mL}$, Figure 4E) reduced their viability. However, no change was observed in R250-exposed cells (Figure 4D). 

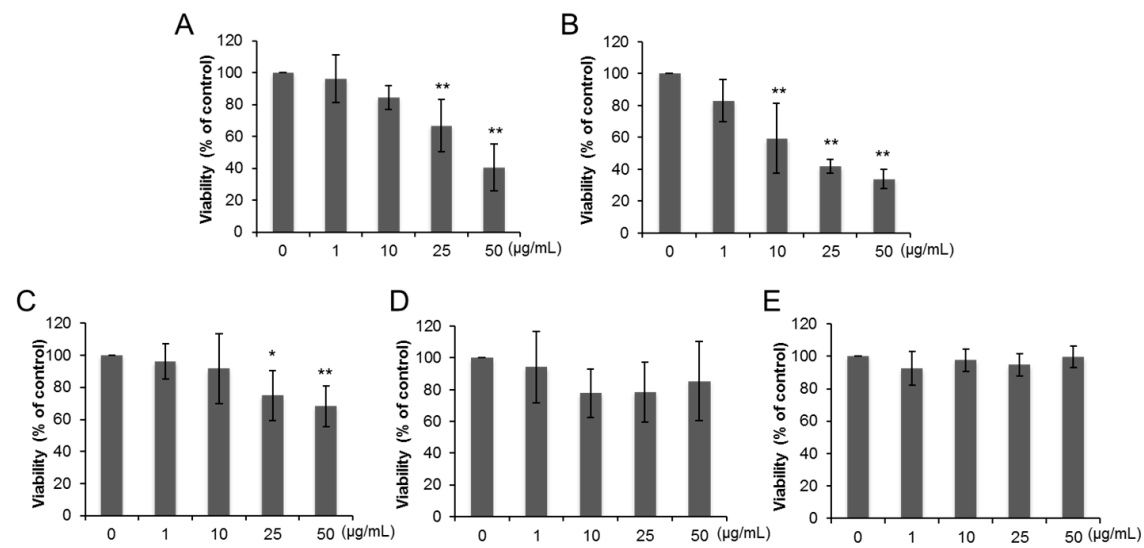

Figure 2. Cytotoxic effects of dispersed $\mathrm{TiO}_{2}$ particles on THP-1 macrophages. Cytotoxicity was measured by 3-(4,5-dimethylthiazol-2-yl)-5-(3-carboxymethoxyphenyl)-2-(4-sulfophenyl)-2H-tetrazo lium (MTS) assay (Promega, Madison, WI, USA). THP-1 macrophages were exposed to (A) A50; (B) A100; (C) R50; (D) R250; and (E) P25 at concentrations ranging from 1 to $50 \mu \mathrm{g} / \mathrm{mL}$ for $24 \mathrm{~h}$. Data are mean $\pm \mathrm{SD}$ of six experiments. ${ }^{*} p<0.05$ vs. control $(0 \mu \mathrm{g} / \mathrm{mL}) .{ }^{* *} p<0.01$ vs. control $(0 \mu \mathrm{g} / \mathrm{mL})$.
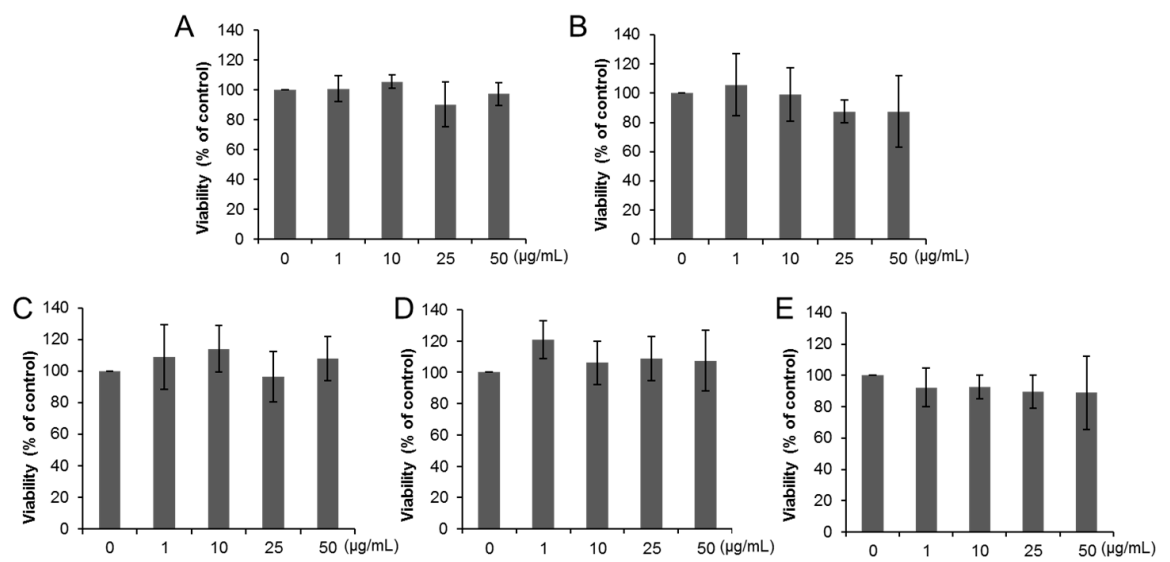

Figure 3. Cytotoxic effects of dispersed $\mathrm{TiO}_{2}$ particles on Caco-2 cells. Caco-2 cells were exposed to (A) A50; (B) A100; (C) R50; (D) R250; and (E) P25 at concentrations ranging from 1 to $50 \mu \mathrm{g} / \mathrm{mL}$ for 24 h. Data are mean \pm SD of six experiments.
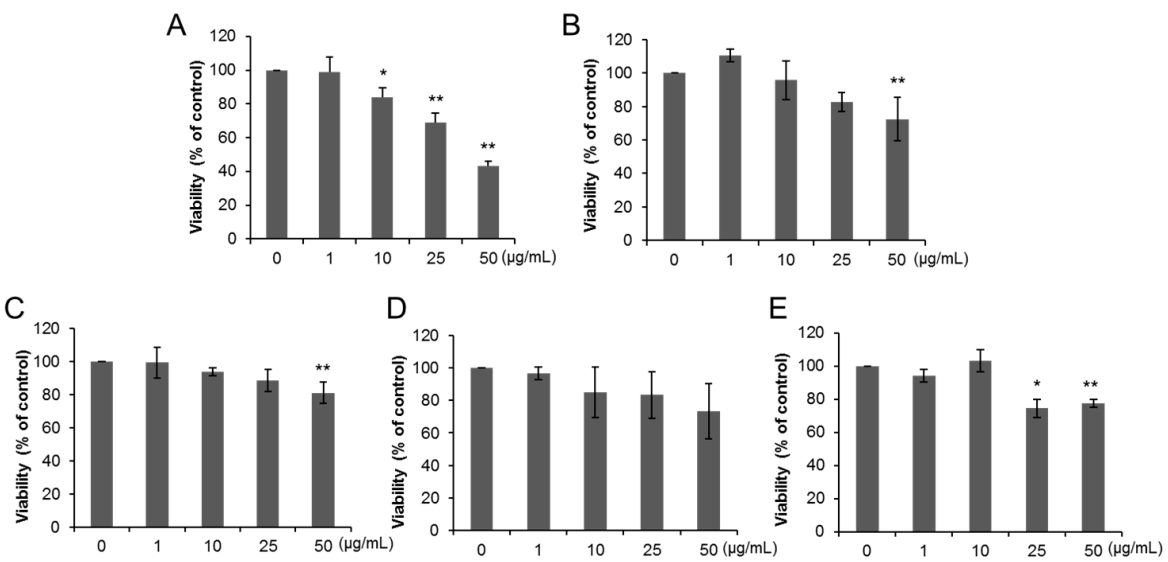

Figure 4. Cytotoxic effects of dispersed $\mathrm{TiO}_{2}$ particles on Caco-2 cells. Caco-2 cells were exposed to (A) A50; (B) A100; (C) R50; (D) R250; and (E) P25 at concentrations ranging from 1 to $50 \mu \mathrm{g} / \mathrm{mL}$ for $72 \mathrm{~h}$. Data are mean $\pm \mathrm{SD}$ of six experiments. ${ }^{*} p<0.05 v$ s. control $(0 \mu \mathrm{g} / \mathrm{mL}) .{ }^{* *} p<0.01 v s$. control $(0 \mu \mathrm{g} / \mathrm{mL})$. 


\subsection{Effects of Exposure on Accumulation of Reactive Oxygen Species (ROS)}

ROS production occurs as the initial cellular response to foreign materials and the maximum ROS levels were found at 2-6-h exposure to $\mathrm{TiO}_{2} \mathrm{NPs}$ by a previous in vitro study [16]. Therefore, we examined the effects of 3-h exposure of THP- 1 macrophages and Caco- 2 cells to $\mathrm{TiO}_{2}$ particles $(25$ and $50 \mu \mathrm{g} / \mathrm{mL}$ ) on ROS production. Exposure to each type of $\mathrm{TiO}_{2}$ particles significantly increased ROS levels in THP-1 macrophages (Figure 5A), especially A50-exposed cells, and Caco-2 cells (Figure 5B).

A

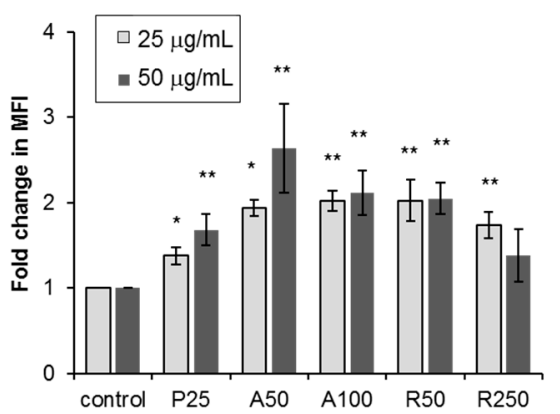

B

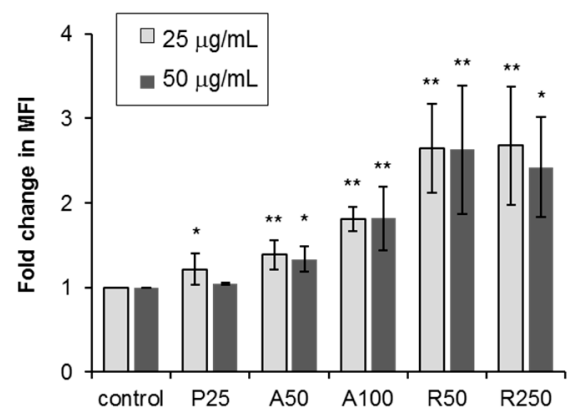

Figure 5. Effects of exposure of (A) THP-1 macrophages and (B) Caco-2 cells to dispersed $\mathrm{TiO}_{2}$ particles (concentration: 25 and $50 \mu \mathrm{g} / \mathrm{mL}$, for $3 \mathrm{~h}$ ) on ROS production. Data are mean $\pm \mathrm{SD}$ of four experiments. ${ }^{*} p<0.05$ vs. control $(0 \mu \mathrm{g} / \mathrm{mL}) .{ }^{* *} p<0.01$ vs. control $(0 \mu \mathrm{g} / \mathrm{mL})$.

\subsection{Effects of Exposure on Interleukin (IL)-1 $\beta$ Levels in THP-1 Macrophages}

Increased production of inflammatory cytokine, IL-1 $\beta$, was noted in THP-1 macrophages after 24-h exposure to A50, and such increase was dose-dependent, and the increase was significant at $50 \mu \mathrm{g} / \mathrm{mL}$ of A50 (Figure 6). However, exposure to other $\mathrm{TiO}_{2}$ particles had no significant effect on IL-1 $\beta$ level.

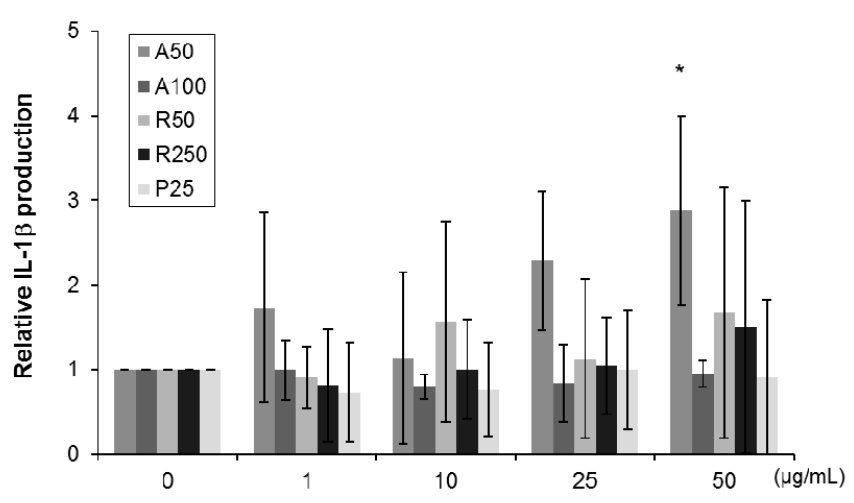

Figure 6. Effects of exposure of THP- 1 macrophages to various $\mathrm{TiO}_{2}$ particles (concentration: 1-50 $\mu \mathrm{g} / \mathrm{mL}$ for $24 \mathrm{~h}$ ) on IL-1 $\beta$ production. Data are mean $\pm \mathrm{SD}$ of three or four experiments. ${ }^{*} p<0.05 v s$. control $(0 \mu \mathrm{g} / \mathrm{mL})$.

\subsection{Effects of Exposure on Expression of IL-8 in Colorectal Adenocarcinoma (Caco-2) Cells}

We measured IL-8 expression in Caco-2 cells after 3- and 6-h exposure to particles because previous reports showed that inflammatory cytokine expression induced by NPs was detected after 1-6-h exposure [17,18]. There were no significant changes in IL-8 mRNA expression level in Caco-2 cells following 3-h exposure, irrespective of the type of $\mathrm{TiO}_{2}$ particle $(25 \mathrm{or} 50 \mu \mathrm{g} / \mathrm{mL}$ ) (data not shown). However, exposure to $50 \mu \mathrm{g} / \mathrm{mL}$ of A50 for $6 \mathrm{~h}$ significantly increased IL-8 mRNA expression in Caco-2 cells (Figure 7). 


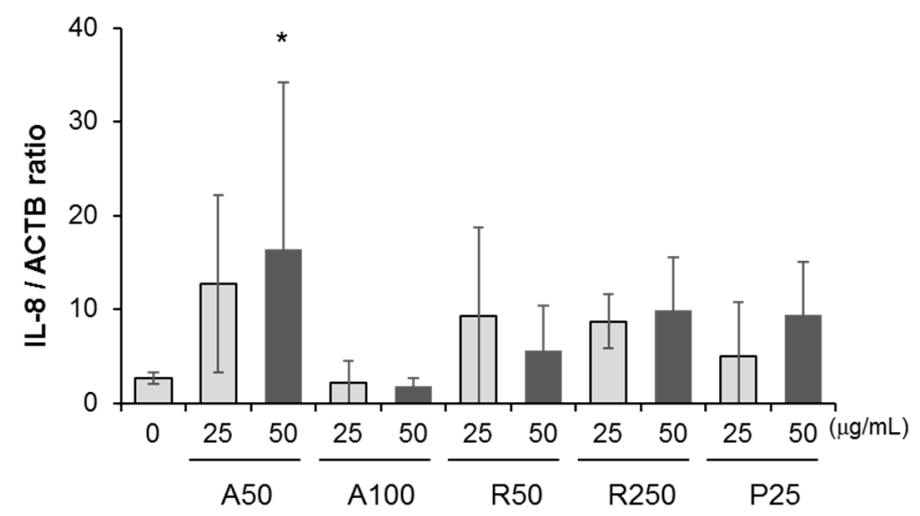

Figure 7. Effects of exposure of Caco-2 cells to various $\mathrm{TiO}_{2}$ particles (concentration: 25 and $50 \mu \mathrm{g} / \mathrm{mL}$ for $6 \mathrm{~h}$ ) on IL-8 mRNA expression level. Data are mean \pm SD of four experiments. ${ }^{*} p<0.05$ vs. control $(0 \mu \mathrm{g} / \mathrm{mL})$.

\section{Discussion}

In the present study, we examined the effects of exposure to different crystal structures and sizes of $\mathrm{TiO}_{2}$ particles in Caco-2 cells and THP-1 monocyte-derived macrophages. Our results indicated that anatase $\mathrm{TiO}_{2} \mathrm{NPs}$ induced inflammatory responses compared with other $\mathrm{TiO}_{2}$ particles.

Although the primary particle size of $\mathrm{TiO}_{2}$ particles is around $200-300 \mathrm{~nm}$, smaller $\mathrm{TiO}_{2} \mathrm{NPs}$ measuring 1-50 $\mathrm{nm}$ are currently used for the purpose of ultraviolet (UV) protection and photocatalytic activity. Previous studies examined the effects of inhalation exposure on inflammation and showed that ultrafine particles induced stronger inflammatory responses than fine particles [19]. On the other hand, pulmonary instillation studied showed that nanoscale particle types of $\mathrm{TiO}_{2}$ were not more cytotoxic or inflammogenic to the lung compared with larger sized particles of similar composition [20]. Other studies showed that inhalation of rutile ultrafine- $\mathrm{TiO}_{2}$ particles was less likely to be associated with adverse pulmonary health effects compared with anatase ultrafine- $\mathrm{TiO}_{2}$ particles [21]. Sayer et al. [22] showed that anatase $\mathrm{TiO}_{2}$ particles were 100 times more toxic than an equivalent sample of rutile $\mathrm{TiO}_{2}$ particles in human dermal fibroblasts and human lung epithelial cells. However, these studies focused mainly on the pulmonary toxicity of $\mathrm{TiO}_{2} \mathrm{NPs}$ following intratracheal instillation and inhalation. Since $\mathrm{TiO}_{2}$ NPs have also been used recently as a white pigment and as a food additive for food coloring, determination of the effects of $\mathrm{TiO}_{2} \mathrm{NPs}$ on the intestine is urgently needed for safety assessment of these particles.

The present study investigated the effects of exposure to different sizes of anatase and rutile $\mathrm{TiO}_{2}$ particles. The MTS assay showed that incubation of THP-1 macrophages in the presence of anatase $\mathrm{TiO}_{2}$ particles significantly reduced cell viability compared with rutile $\mathrm{TiO}_{2}$ particles. Moreover, incubation of Caco-2 cells in the presence of anatase $\mathrm{TiO}_{2}$ particles, especially anatase $\mathrm{TiO}_{2} \mathrm{NPs}$ of primary particle size of $50 \mathrm{~nm}$, significantly reduced cell viability after exposure for $72 \mathrm{~h}$. We have recently reported the cytotoxicity of zinc oxide ( $\mathrm{ZnO}) \mathrm{NPs}$, but not $\mathrm{P} 25 \mathrm{TiO}_{2} \mathrm{NPs}$, on endothelial cells [23]. The typical crystalline composition of $\mathrm{P}_{25} \mathrm{TiO}_{2} \mathrm{NPs}$ was around $80 \%$ anatase and $20 \%$ rutile [24]. The present study also showed that 24-h-exposure to $\mathrm{P} 25 \mathrm{TiO}_{2} \mathrm{NPs}$ was not cytotoxic for both THP- 1 macrophages and Caco-2 cells. The results indicate that anatase $\mathrm{TiO}_{2} \mathrm{NPs}$ is more toxic than rutile $\mathrm{TiO}_{2}$ particles, suggesting that $\mathrm{TiO}_{2}$ particle toxicity in human intestinal cells depends on the particle size and crystalline structure.

Previous acute oral toxicity studies showed that $\mathrm{TiO}_{2} \mathrm{NPs}$ had very low toxicity in animals $[25,26]$. Moreover, oral administration of $\mathrm{TiO}_{2} \mathrm{NPs}$ showed low absorption and narrow range of organ distribution [27], but slow tissue elimination [28]. Although data using cultured cells are not a substitute for whole animal studies, the use of simple cell culture models with endpoints that can identify the mechanism of cellular responses or toxicity can be the basis for further assessment of the potential risk of material exposure. Previous cell culture studies showed that $\mathrm{TiO}_{2} \mathrm{NPs}_{\mathrm{N}}$ induced 
oxidative stress and increased IL-1 $\beta$ levels in murine dendritic cells [29]. Yazdi et al. [30] showed

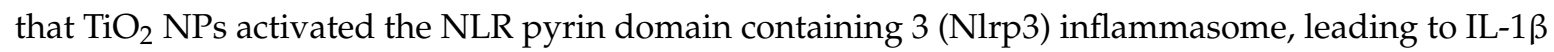
release in murine and human macrophages and human keratinocytes. Moreover, comparison of IL-1 $\beta$ production in response to exposure to various engineered NPs showed that high concentration $(500 \mu \mathrm{g} / \mathrm{mL})$ of smaller anatase and larger rutile $\mathrm{TiO}_{2}$ particles induced high production of IL-1 $\beta$ [31]. Another study showed that $\mathrm{TiO}_{2}$ nanobelts, but not P25 or anatase $\mathrm{TiO}_{2}$, induced IL-1 $\beta$ in THP-1 cells [32]. Yazdi et al. [30] also demonstrated that chemical ROS scavenger diminished IL-1 $\beta$ secretion triggered by $\mathrm{TiO}_{2}$ NPs in THP-1 cells, suggesting that ROS production induced inflammatory cytokine production after exposure to $\mathrm{TiO}_{2} \mathrm{NPs}$. On the other hands, other previous reports showed that ROS was not essential for IL-1 $\beta$ production via the Nlrp3 inflammasome [33,34]. In the present study, the production of IL-1 $\beta$ was significantly increased in THP-1 macrophages after exposure to $50 \mu \mathrm{g} / \mathrm{mL}$ of anatase $\mathrm{TiO}_{2}$ NPs. Since the level of ROS was also most elevated in THP-1 macrophages exposed to $50 \mu \mathrm{g} / \mathrm{mL}$ of anatase $\mathrm{TiO}_{2} \mathrm{NPs}$ compared with other particles, it seems that anatase $\mathrm{TiO}_{2}$ nanoparticles induce inflammatory responses through accumulation of ROS in THP-1 macrophages. However, ROS might be not necessarily the main contributing factor of particles-induced IL- $1 \beta$ production in THP-1 macrophages because $\mathrm{ROS}$ level was increased after exposure to all $\mathrm{TiO}_{2}$ particles.

Orally ingested NPs are uptaken by epithelial cells and M cells in Peyer's patches through the process of endocytosis, invasion by over-adsorption in cell gaps, and/or intrusion by passing through the tight junctions between cells [35]. Fine and ultrafine particles are potent adjuvants in antigen-mediated immune responses and are increasingly associated with inflammatory bowel diseases, such as Crohn's disease [36]. ZnO NPs have been shown to induce cytotoxicity associated with overproduction of ROS in Caco-2 cells [37,38]. ZnO NPs has also been reported to induce inflammatory responses and increase the release of IL-8 in Caco-2 cells [37,39]. The present study found IL-8 over-expression in Caco-2 cells exposed to anatase $\mathrm{TiO}_{2} \mathrm{NPs}$ for $6 \mathrm{~h}$. Interestingly, a previous similar study showed that exposure to $10 \mu \mathrm{g} / \mathrm{mL}$ of $\mathrm{P}_{25 \mathrm{TiO}_{2}} \mathrm{NPs}$ for $24 \mathrm{~h}$ led to increased IL-8 production in Caco-2 cells [40]. On the other hand, De Angelis et al. [39] demonstrated the induction of IL-8 production after 6-h exposure to $\mathrm{ZnO}$ NPs, but not anatase $\mathrm{TiO}_{2} \mathrm{NPs}$. The smaller mean hydrodynamic diameter of anatase $\mathrm{TiO}_{2} \mathrm{NPs}$ estimated in the present study, relative to that of the above study [40] could perhaps explain the differences between the two studies. In the present study, there was no correlation between the induction of IL-8 production and ROS production in Caco-2 cells after $\mathrm{TiO}_{2}$ particles exposure. As shown in a previous report [41], oxidative stress induced by various NPs is an early event as the initial cellular response and ROS might not play a role in the impairment of inflammation-related pathway. $\mathrm{TiO}_{2} \mathrm{NPs}$ can induce nuclear factor (NF)- $\mathrm{kB}$ activity by subsequent degradation of inhibitor (I) $k-B$ in airway epithelial and endothelial cells [42,43]. The presence of a binding site for NF- $\mathrm{KB}$ in the promoter region of IL- 8 and enhanced IL-8 transcription following NF- $\mathrm{KB}$ binding, suggests that IL-8 expression could be up-regulated through NF- $\mathrm{KB}$ activation following exposure to anatase $\mathrm{TiO}_{2} \mathrm{NPs}$.

The present study indicated that anatase $\mathrm{TiO}_{2} \mathrm{NPs}$ induced inflammatory responses compared with other $\mathrm{TiO}_{2}$ particles. However, $\mathrm{Zijno}$ et al. [44] recently compared the genotoxicity of $\mathrm{TiO}_{2}$ and $\mathrm{ZnO}$ NPs and demonstrated that only $\mathrm{ZnO}$ NPs were genotoxic, including destruction of micronuclei and DNA damage, although both NPs produced ROS in Caco-2 cells. Moreover, native $\mathrm{TiO}_{2} \mathrm{NPs}$ and pretreated $\mathrm{TiO}_{2} \mathrm{NPs}$ with the digestion simulation fluid or bovine serum albumin did not show significant toxicity in both Caco-2 cells and Caco-2 monolayers [45]. Janer et al. [46] suggested that the Caco-2 monolayer system is likely to underestimate the effects of oral absorption of NPs due to the fact that NPs were observed in Peyer Patch cells in the oral absorption study. The development of safe and effective NPs is important for advancement of technology and for healthy lives. There is no doubt a need to elucidate the effects and mechanisms of $\mathrm{TiO}_{2} \mathrm{NPs}$ in the intestine using co-culture models, such as microfold (M) cells or intestinal epithelial cells ingested particles in vivo. 


\section{Experimental Section}

\section{1. $\mathrm{TiO}_{2}$ Particles Preparation and Characterization}

The $\mathrm{TiO}_{2}$ particles used in the present study were A50 (anatase, primary diameter: $50 \mathrm{~nm}$ ) (mkNano, Mississauga, ON, Canada), A100 (anatase, primary diameter: $100 \mathrm{~nm}$ ) (mkNano), R50 (rutile, primary diameter: $50 \mathrm{~nm}$ ) (mkNano), R250 (rutile, primary diameter: $250 \mathrm{~nm})(\mathrm{mkNano})$, and P25 (80\% anatases $/ 20 \%$ rutile, primary diameter: $21 \mathrm{~nm}$ ) (Degussa, Germany). We characterized previously $\mathrm{P} 25 \mathrm{TiO}_{2}$ NPs from the same lot by DLS as well as by transmission electron microscope (TEM, JEM-1011; JEOL, Tokyo, Japan), and then established a suitable protocol for the preparation of a suspension of $\mathrm{TiO}_{2} \mathrm{NPs}$ [14]. NPs were suspended in serum-containing culture media and dispersed using a sonicator (model 450, Branson Sonifier, Danbury, CT, USA) set at $80 \%$ pulsed mode, $100 \mathrm{~W}$, and $15 \mathrm{~min}$. The hydrodynamic size of the particles in the medium was measured four times after $1 \mathrm{~h}$ on standing using DLS technology with zetasizer Nano-S (Malvern Instruments, Worcestershire, UK). The dispersion status was described by the intensity-weighted hydrodynamic average diameter ( $z$-average) and PdI, which reflect the broadness of the size distribution (scale range from 0 to 1 , with 0 being monodispersion and 1 being polydispersion). To investigate the electrophoretic mobility of the particles, $\zeta$ potential of the particles in each medium was measured three times with Photal LEZA-600 (Otsuka Electronics, Tokyo, Japan).

\subsection{Cell Culture}

Macrophages play a key role in the body's defense to particles as well as in inflammatory-related health effects. Human monocytic leukemia cells cell line THP-1 (ATCC, TIB202, Manassas, VA, USA) were cultured in RPMI 1640 medium (Life Technologies, Carlsbad, CA, USA) supplemented with 10\% $(v / v)$ FBS, 100 units $/ \mathrm{mL}$ penicillin, and $100 \mu \mathrm{g} / \mathrm{mL}$ streptomycin. THP-1 cells were differentiated to macrophages with $0.1 \mu \mathrm{g} / \mathrm{mL}$ phorbol 12-myristate 13-acetate (PMA; Sigma-Aldrich, St. Louis, MO, USA) for $72 \mathrm{~h}$, before experimentation. The human colon colorectal adenocarcinoma cell line Caco-2 which are of intestinal epithelial origin, obtained from American Type Culture Collection (ATCC; HTB-37), were cultured in DMEM medium (Life Technologies) supplemented with 10\% $(v / v)$ FBS, 0.1 $\mathrm{mM}$ MEM NEAA, 100 units $/ \mathrm{mL}$ penicillin, and $100 \mu \mathrm{g} / \mathrm{mL}$ streptomycin at $37^{\circ} \mathrm{C}$ in $5 \% \mathrm{CO}_{2}$.

\subsection{Cell Viability Assay}

THP-1 monocytes were seeded at $1.5 \times 10^{4}$ cells/well on 96-well plates and differentiated to macrophages with PMA before the experiment as described above. Caco- 2 cells were seeded overnight at $1.5 \times 10^{4}$ cells per well on 96-well plates before the experiment. Particles were dispersed in each serum-containing cell culture medium at a final concentration ranging from 1 to $50 \mu \mathrm{g} / \mathrm{mL}$. The previous studies demonstrated that $\mathrm{TiO}_{2} \mathrm{NPs}$ induced a pronounced inflammatory response at the concentration of 10-200 $\mu \mathrm{g} / \mathrm{mL}$ in in vitro models of gut epithelium [47]. Also, the concentration range corresponded to the dose used in our previous study [23]. Cell viability was determined after incubation with the dispersed $\mathrm{TiO}_{2}$ particles for 24 or $72 \mathrm{~h}$, by MTS assay based on the CellTiter 96 AQueous One Solution (Promega, Madison, WI, USA), which measures mitochondrial function; the latter correlates with cell viability. The serum-containing cell culture medium was used during incubation with the particles. After the incubation, the cells were incubated with fresh medium (phenol red-free) containing MTS reagent for $1 \mathrm{~h}$ before measurements at an absorbance of $490 \mathrm{~nm}$. The effect of particles on cell proliferation was expressed as percentage of inhibition of cell growth relative to the control.

\subsection{Measurement of ROS Production}

Cellular ROS production triggered by $\mathrm{TiO}_{2}$ particles was assayed by staining with 5-(and-6)-chloromethyl-2', $7^{\prime}$-dichlorodihydro fluorescein diacetate, acetyl ester (CM- $\left.\mathrm{H}_{2} \mathrm{DCFDA}\right)$ (Life Technologies) followed by flow cytometry (FACS CantoII, BD Bioscience, Franklin Lakes, NJ, 
USA). Before the experiment, THP- 1 monocytes were seeded at $3 \times 10^{5}$ cells / well onto 24 -well plates and allowed to differentiate into macrophages using PMA as described above. Caco- 2 cells were seeded overnight at $3 \times 10^{5}$ cells /well onto 24-well plates before the experiment. After exposure to $\mathrm{TiO}_{2}$ particles for $3 \mathrm{~h}$, THP- 1 macrophages and Caco- 2 cells $\left(3 \times 10^{5}\right.$ cells $)$ were loaded with $5 \mu \mathrm{M}$ $\mathrm{CM}-\mathrm{H}_{2}$ DCFDA for $30 \mathrm{~min}$ at $37^{\circ} \mathrm{C}$ and analyzed by flow cytometry. Ten thousand cells per sample were acquired in histograms using FlowJo software (Flowjo, Ashland, OR, USA). Dead cells and debris were excluded by electronic gating using forward and side scatter measurements.

\subsection{Measurement of IL-1ß Production}

Before the experiment, THP- 1 monocytes were seeded at $1.5 \times 10^{4}$ cells/well onto 96-well plates and differentiated to macrophages using PMA as described above. THP-1 macrophages were exposed to 25 or $50 \mu \mathrm{g} / \mathrm{mL}$ of the suspended particles for $24 \mathrm{~h}$. The cell culture medium was collected and centrifuged at $10,000 \times g$ to remove cell debris and suspended $\mathrm{TiO}_{2}$ particles. The final supernatant was stored at $-20^{\circ} \mathrm{C}$ until cytokine analysis. The amount of IL-1 $\beta$ in the cell medium was measured using ELISA (Biolegend, San Diego, CA, USA) according to the protocol supplied by the manufacturer. Changes in color intensity were quantified by a plate reader (Bio-Rad Laboratories, Hercules, CA, USA).

\subsection{Analysis of IL-8 Expression}

Caco- 2 cells $\left(2 \times 10^{5}\right.$ cells) were seeded onto 12 -well plates and exposed to 25 or $50 \mu \mathrm{g} / \mathrm{mL}$ of the suspended particles for 3 or $6 \mathrm{~h}$. Total RNA from the cells was isolated by using ReliaPrep RNA cell miniprep system (Promega) using the protocol provided by the manufacturer. The concentration of total RNA was quantified by spectrophotometry (ND-1000; NanoDrop Technologies, Wilmington, DE, USA). RNA was reverse transcribed to single-strand cDNA using SuperScript III First-Strand Synthesis System for RT-PCR (Life Technologies). cDNA ( $n=4$ in each group) was subjected to quantitative PCR analysis with FastStart Universal Probe Master Mix (Roche, Basel, Switzerland) and primers for IL-8 using an ABI 7000 Real-Time PCR system (Life Technologies), as described previously [48]. The gene expression level was normalized to that of $\beta$-actin in the same cDNA.

\subsection{Statistical Analysis}

All parameters were expressed as mean \pm standard deviation (SD). Differences between groups were analyzed by one-way analysis of variance (ANOVA) followed by Dunnett's post hoc test. A $p$ value less than 0.05 was considered statistically significant.

\section{Conclusions}

Since $\mathrm{TiO}_{2}$ nanoparticles are widely used in various fields, including the food industry, understanding their behavior and effects on the intestine is essential for risk assessment. In this study, we examined the effects of $\mathrm{TiO}_{2}$ particles of different crystal structures and sizes in Caco-2 cells and THP- 1 monocyte-derived macrophages. Exposure to $50 \mu \mathrm{g} / \mathrm{mL}$ of anatase $\mathrm{TiO}_{2}$ nanoparticles increased the production of IL-1 $\beta$ in THP-1 macrophages and increased IL-8 expression in Caco-2 cells. These results indicate that anatase $\mathrm{TiO}_{2}$ nanoparticles, but not other $\mathrm{TiO}_{2}$ particles, seem to induce inflammatory response.

Acknowledgments: The authors thank Kumi Nakao for the help in preparation of the manuscript. This work was supported in part by grants from the Japan Society for the Promotion of Science (NEXT Program \#LS056 and grants-in aid for Scientific Research \#25460798 and \#26293149).

Author Contributions: Saeko Tada-Oikawa performed the experiments, analyzed the data, and wrote the manuscript. Sahoko Ichihara designed the study, designed and supervised the project and contributed to data interpretation and manuscript revision. Hitomi Fukatsu, Yuka Shimanuki, and Natsuki Tanaka were involved in cytokine analysis. Eri Watanabe was involved in measurement of $\zeta$ potential. Yuka Suzuki, Masahiko Murakami, and Jie Chang were involved in cell culture and sample preparation. Kiyora Izuoka and Wenting Wu were involved in particle dispersion. Gaku Ichihara and Yoshiji Yamada reviewed the manuscript and provided comments. All authors read and approved the final manuscript. 
Conflicts of Interest: The authors declare no conflict of interest.

$\begin{array}{cl}\text { Abbreviations } & \\ \mathrm{NPs} & \text { nanoparticles } \\ \mathrm{TiO}_{2} & \text { titanium dioxide } \\ \mathrm{DLS} & \text { dynamic light scattering } \\ \mathrm{PdI} & \text { polydispersity index } \\ \mathrm{ROS} & \text { reactive oxygen species }\end{array}$

\section{References}

1. Gwinn, M.R.; Vallyathan, V. Nanoparticles: Health effects-Pros and cons. Environ. Health Perspect. 2006, 114, 1818-1825. [CrossRef] [PubMed]

2. Nel, A.E.; Mädler, L.; Velegol, D.; Xia, T.; Hoek, E.M.; Somasundaran, P.; Klaessig, F.; Castranova, V.; Thompson, M. Understanding biophysicochemical interactions at the nano-bio interface. Nat. Mater. 2009, 8, 543-557. [CrossRef] [PubMed]

3. Wiesenthal, A.; Hunter, L.; Wang, S.; Wickliffe, J.; Wilkerson, M. Nanoparticles: Small and mighty. Int. J. Dermatol. 2011, 50, 247-254. [CrossRef] [PubMed]

4. Chaudhry, Q.; Scotter, M.; Blackburn, J.; Ross, B.; Boxall, A.; Castle, L.; Aitken, R.; Watkins, R. Applications and implications of nanotechnologies for the food sector. Food Addit. Contam. A Chem. Anal. Control Expo. Risk Assess. 2008, 25, 241-258. [CrossRef] [PubMed]

5. Chen, X.; Mao, S.S. Titanium dioxide nanomaterials: Synthesis, properties, modifications, and applications. Chem. Rev. 2007, 107, 2891-2959. [CrossRef] [PubMed]

6. Macwan, D.P.; Dave, P.N.; Chaturvedi, S. A review on nano- $\mathrm{TiO}_{2}$ sol-gel type syntheses and its applications. J. Mater. Sci. 2011, 46, 3669-3686. [CrossRef]

7. Long, T.C.; Tajuba, J.; Sama, P.; Saleh, N.; Swartz, C.; Parker, J.; Hester, S.; Lowry, G.V.; Veronesi, B. Nanosize titanium dioxide stimulates reactive oxygen species in brain microglia and damages neurons in vitro. Environ. Health Perspect. 2007, 115, 1631-1637. [CrossRef] [PubMed]

8. Bouhaik, I.S.; Leroy, P.; Ollivier, P.; Azaroual, M.; Mercury, L. Influence of surface conductivity on the apparent zeta potential of $\mathrm{TiO} 2$ nanoparticles: Application to the modeling of their aggregation kinetics. J. Colloid Interface Sci. 2013, 406, 75-85. [CrossRef] [PubMed]

9. Liu, K.; Lin, X.; Zhao, J. Toxic effects of the interaction of titanium dioxide nanoparticles with chemicals or physical factors. Int. J. Nanomed. 2013, 8, 2509-2520.

10. Rashidi, L.; Khosravi-Darani, K. The applications of nanotechnology in food industry. Crit. Rev. Food Sci. Nutr. 2011, 51, 723-730. [CrossRef] [PubMed]

11. Weir, A.; Westerhoff, P.; Fabricius, L.; Hristovski, K.; von Goetz, N. Titanium dioxide nanoparticles in food and personal care products. Environ. Sci. Technol. 2012, 46, 2242-2250. [CrossRef] [PubMed]

12. Chen, X.X.; Cheng, B.; Yang, Y.X.; Cao, A.; Liu, J.H.; Du, L.J.; Liu, Y.; Zhao, Y.; Wang, H. Characterization and preliminary toxicity assay of nano-titanium dioxide additive in sugar-coated chewing gum. Small 2013, 9, 1765-1774. [CrossRef] [PubMed]

13. Hussain, S.; Vanoirbeek, J.A.J.; Luyts, K.; de Vooght, V.; Verbeken, E.; Thomassen, L.C.J.; Martens, J.A.; Dinsdale, D.; Boland, S.; Marano, F.; et al. Lung exposure to nanoparticles modulates an asthmatic response in a mouse model. Eur. Respir. J. 2011, 37, 299-309. [CrossRef] [PubMed]

14. Wu, W.; Ichihara, G.; Suzuki, Y.; Izuoka, K.; Oikawa-Tada, S.; Chang, J.; Sakai, K.; Miyazawa, K.; Porter, D.; Castranova, V.; et al. Dispersion method for safety research on manufactured nanomaterials. Ind. Health 2013, 52, 54-65. [CrossRef] [PubMed]

15. Wu, W.; Ichihara, G.; Hashimoto, N.; Hasegawa, Y.; Hayashi, Y.; Tada-Oikawa, S.; Suzuki, Y.; Chang, J.; Kato, M.; D'Alessandro-Gabazza, C.N.; et al. Synergistic effect of bolus exposure to zinc oxide nanoparticles on bleomycin-induced secretion of pro-fibrotic cytokines without lasting fibrotic changes in murine lungs. Int. J. Mol. Sci. 2014, 16, 660-676. [CrossRef] [PubMed] 
16. Huerta-García, E.; Pérez-Arizti, J.A.; Márquez-Ramírez, S.G.; Delgado-Buenrostro, N.L.; Chirino, Y.I.; Iglesias, G.G.; López-Marure, R. Titanium dioxide nanoparticles induce strong oxidative stress and mitochondrial damage in glial cells. Free Radic. Biol. Med. 2014, 73, 84-94. [CrossRef] [PubMed]

17. Ishimoto, Y.; Nakai, Y.; Satsu, H.; Totsuka, M.; Shimizu, M. Transient up-regulation of immunity- and apoptosis-related genes in Caco-2 cells cocultured with THP-1 cells evaluated by DNA microarray analysis. Biosci. Biotechnol. Biochem. 2010, 74, 437-439. [CrossRef] [PubMed]

18. Mastrofrancesco, A.; Alfè, M.; Rosato, E.; Gargiulo, V.; Beatrice, C.; Di Blasio, G.; Zhang, B.; Su, D.S.; Picardo, M.; Fiorito, S. Proinflammatory effects of diesel exhaust nanoparticles on scleroderma skin cells. J. Immunol. Res. 2014, 2014, 138751. [CrossRef] [PubMed]

19. Oberdörster, G.; Maynard, A.; Donaldson, K.; Castranova, V.; Fitzpatrick, J.; Ausman, K.; Carter, J.; Karn, B.; Kreyling, W.; Lai, D.; et al. Principles for characterizing the potential human health effects from exposure to nanomaterials: Elements of a screening strategy. Part. Fibre Toxicol. 2005, 2, 8. [CrossRef] [PubMed]

20. Warheit, D.B.; Webb, T.R.; Sayes, C.M.; Colvin, V.L.; Reed, K.L. Pulmonary instillation studies with nanoscale $\mathrm{TiO}_{2}$ rods and dots in rats: Toxicity is not dependent upon particle size and surface area. Toxicol. Sci. 2006, 91, 227-236. [CrossRef] [PubMed]

21. Warheit, D.B.; Webb, T.R.; Reed, K.L.; Frerichs, S.; Sayes, C.M. Pulmonary toxicity study in rats with three forms of ultrafine- $\mathrm{TiO}_{2}$ particles: Differential responses related to surface properties. Toxicology 2007, 230, 90-104. [CrossRef] [PubMed]

22. Sayes, C.M.; Wahi, R.; Kurian, P.A.; Liu, Y.; West, J.L.; Ausman, K.D.; Warheit, D.B.; Colvin, V.L. Correlating nanoscale titania structure with toxicity: A cytotoxicity and inflammatory response study with human dermal fibroblasts and human lung epithelial cells. Toxicol. Sci. 2006, 92, 174-185. [CrossRef] [PubMed]

23. Suzuki, Y.; Tada-Oikawa, S.; Ichihara, G.; Yabata, M.; Izuoka, K.; Suzuki, M.; Sakai, K.; Ichihara, S. Zinc oxide nanoparticles induce migration and adhesion of monocytes to endothelial cells and accelerate foam cell formation. Toxicol. Appl. Pharmacol. 2014, 278, 16-25.

24. Ohtani, B.; Prieto-Mahaney, O.O.; Li, D.; Abe, R. What is Degussa (Evonik) P25? Crystalline composition analysis, reconstruction from isolated pure particles and photocatalytic activity test. J. Photochem. Photobiol. A 2010, 216, 179-182. [CrossRef]

25. Wang, J.; Zhou, G.; Chen, C.; Yu, H.; Wang, T.; Ma, Y.; Jia, G.; Gao, Y.; Li, B.; Sun, J.; et al. Acute toxicity and biodistribution of different sized titanium dioxide particles in mice after oral administration. Toxicol. Lett. 2007, 168, 176-185. [CrossRef] [PubMed]

26. Warheit, D.B.; Hoke, R.A.; Finlay, C.; Donner, E.M.; Reed, K.L.; Sayes, C.M. Development of a base set of toxicity tests using ultrafine $\mathrm{TiO}_{2}$ particles as a component of nanoparticle risk management. Toxicol. Lett. 2007, 10, 99-110. [CrossRef] [PubMed]

27. Cho, W.S.; Kang, B.C.; Lee, J.K.; Jeong, J.; Che, J.H.; Seok, S.H. Comparative absorption, distribution, and excretion of titanium dioxide and zinc oxide nanoparticles after repeated oral administration. Part. Fibre Toxicol. 2013, 10, 9. [CrossRef] [PubMed]

28. Geraets, L.; Oomen, A.G.; Krystek, P.; Jacobsen, N.R.; Wallin, H.; Laurentie, M.; Verharen, H.W.; Brandon, E.F.; de Jong, W.H. Tissue distribution and elimination after oral and intravenous administration of different titanium dioxide nanoparticles in rats. Part. Fibre Toxicol. 2014, 11, 30. [CrossRef] [PubMed]

29. Winter, M.; Beer, H.D.; Hornung, V.; Krämer, U.; Schins, R.P.; Förster, I. Activation of the inflammasome by amorphous silica and $\mathrm{TiO}_{2}$ nanoparticles in murine dendritic cells. Nanotoxicology 2011, 5, 326-340. [CrossRef] [PubMed]

30. Yazdi, A.S.; Guarda, G.; Riteau, N.; Drexler, S.K.; Tardivel, A.; Couillin, I.; Tschopp, J. Nanoparticles activate the NLR pyrin domain containing 3 (Nlrp3) inflammasome and cause pulmonary inflammation through release of IL-1 $\alpha$ and IL-1 $\beta$. Proc. Natl. Acad. Sci. USA 2010, 107, 19449-19454. [CrossRef] [PubMed]

31. Morishige, T.; Yoshioka, Y.; Tanabe, A.; Yao, X.; Tsunoda, S.; Tsutsumi, Y.; Mukai, Y.; Okada, N.; Nakagawa, S. Titanium dioxide induces different levels of IL-1 $\beta$ production dependent on its particle characteristics through caspase-1 activation mediated by reactive oxygen species and cathepsin B. Biochem. Biophys. Res. Commun. 2010, 392, 160-165. [CrossRef] [PubMed]

32. Xia, T.; Hamilton, R.F.; Bonner, J.C.; Crandall, E.D.; Elder, A.; Fazlollahi, F.; Girtsman, T.A.; Kim, K.; Mitra, S.; Ntim, S.A.; et al. Interlaboratory evaluation of in vitro cytotoxicity and inflammatory responses to engineered nanomaterials: The NIEHS Nano GO Consortium. Environ. Health Perspect. 2013, 121, 683-690. [CrossRef] [PubMed] 
33. Van de Veerdonk, F.L.; Smeekens, S.P.; Joosten, L.A.; Kullberg, B.J.; Dinarello, C.A.; van der Meer, J.W.; Netea, M.G. Reactive oxygen species-independent activation of the IL-1 $\beta$ inflammasome in cells from patients with chronic granulomatous disease. Proc. Natl. Acad. Sci. USA 2010, 16, 3030-3033. [CrossRef] [PubMed]

34. Iyer, S.S.; He, Q.; Janczy, J.R.; Elliott, E.I.; Zhong, Z.; Olivier, A.K.; Sadler, J.J.; Knepper-Adrian, V.; Han, R.; Qiao, L.; et al. Mitochondrial cardiolipin is required for Nlrp3 inflammasome activation. Immunity 2013, 39, 311-323. [CrossRef] [PubMed]

35. Powell, J.J.; Faria, N.; Thomas-McKay, E.; Pele, L.C. Origin and fate of dietary nanoparticles and microparticles in the gastrointestinal tract. J. Autoimmun. 2010, 34, J226-J233. [CrossRef] [PubMed]

36. Lomer, M.C.; Thompson, R.P.; Powell, J.J. Fine and ultrafine particles of the diet: Influence on the mucosal immune response and association with Crohn's disease. Proc. Nutr. Soc. 2002, 61, 123-130. [CrossRef] [PubMed]

37. Gerloff, K.; Pereira, D.I.; Faria, N.; Boots, A.W.; Kolling, J.; Förster, I.; Albrecht, C.; Powell, J.J.; Schins, R.P. Influence of simulated gastrointestinal conditions on particle-induced cytotoxicity and interleukin- 8 regulation in differentiated and undifferentiated Caco-2 cells. Nanotoxicology 2013, 7, 353-366. [CrossRef] [PubMed]

38. Kang, T.; Guan, R.; Chen, X.; Song, Y.; Jiang, H.; Zhao, J. In vitro toxicity of different-sized ZnO nanoparticles in Caco-2 cells. Nanoscale Res. Lett. 2013, 8, 496. [CrossRef] [PubMed]

39. De Angelis, I.; Barone, F.; Zijno, A.; Bizzarri, L.; Russo, M.T.; Pozzi, R.; Franchini, F.; Giudetti, G.; Uboldi, C.; Ponti, J.; et al. Comparative study of $\mathrm{ZnO}$ and $\mathrm{TiO}_{2}$ nanoparticles: Physicochemical characterisation and toxicological effects on human colon carcinoma cells. Nanotoxicology 2013, 7, 1361-1372. [CrossRef] [PubMed]

40. Abbott Chalew, T.E.; Schwab, K.J. Toxicity of commercially available engineered nanoparticles to Caco-2 and SW480 human intestinal epithelial cells. Cell Biol. Toxicol. 2013, 29, 101-116. [CrossRef] [PubMed]

41. Courtois, A.; Andujar, P.; Ladeiro, Y.; Baudrimont, I.; Delannoy, E.; Leblais, V.; Begueret, H.; Galland, M.A.; Brochard, P.; Marano, F.; et al. Impairment of NO-dependent relaxation in intralobar pulmonary arteries: Comparison of urban particulate matter and manufactured nanoparticles. Environ. Health Perspect. 2008, 116, 1294-1299. [CrossRef] [PubMed]

42. Churg, A.; Xie, C.; Wang, X.; Vincent, R.; Wang, R.D. Air pollution particles activate NF-кB on contact with airway epithelial cell surfaces. Toxicol. Appl. Pharmacol. 2005, 208, 37-45. [CrossRef] [PubMed]

43. Montiel-Dávalos, A.; Ventura-Gallegos, J.L.; Alfaro-Moreno, E.; Soria-Castro, E.; García-Latorre, E.; Cabañas-Moreno, J.G.; Ramos-Godinez, M.P.; López-Marure, R. $\mathrm{TiO}_{2}$ nanoparticles induce dysfunction and activation of human endothelial cells. Chem. Res. Toxicol. 2012, 25, 920-930. [CrossRef] [PubMed]

44. Zijno, A.; de Angelis, I.; De Berardis, B.; Andreoli, C.; Russo, M.T.; Pietraforte, D.; Scorza, G.; Degan, P.; Ponti, J.; Rossi, F.; et al. Different mechanisms are involved in oxidative DNA damage and genotoxicity induction by $\mathrm{ZnO}$ and $\mathrm{TiO}_{2}$ nanoparticles in human colon carcinoma cells. Toxicol. Vit. 2015, 29, 1503-1512. [CrossRef] [PubMed]

45. Song, Z.M.; Chen, N.; Liu, J.H.; Tang, H.; Deng, X.; Xi, W.S.; Han, K.; Cao, A.; Liu, Y.; Wang, H. Biological effect of food additive titanium dioxide nanoparticles on intestine: An in vitro study. J. Appl. Toxicol. 2015, 35, 1169-1178. [CrossRef] [PubMed]

46. Janer, G.; Mas del Molino, E.; Fernández-Rosas, E.; Fernández, A.; Vázquez-Campos, S. Cell uptake and oral absorption of titanium dioxide nanoparticles. Toxicol. Lett. 2014, 228, 103-110. [CrossRef] [PubMed]

47. Brun, E.; Barreau, F.; Veronrsi, G.; Fayard, B.; Sorieul, S.; Chaneac, C.; Carapito, T.; Rabilloud, T.; Mabondzo, A.; Herlin-Boime, N.; et al. Titanium dioxide nanoparticle impact and translocation through $e x$ vivo, in vivo and in vitro gut epithelia. Part. Fibre Toxicol. 2014, 11, 13. [CrossRef] [PubMed]

48. Tada-Oikawa, S.; Ichihara, G.; Suzuki, Y.; Izuoka, K.; Yamada, Y.; Mishima, T.; Ichihara, S. Zn(II) released from zinc oxide nano/micro particles suppresses vasculogenesis in human endothelial colony-forming cells. Toxicol. Rep. 2015, 2, 692-701. [CrossRef]

(C) 2016 by the authors; licensee MDPI, Basel, Switzerland. This article is an open access article distributed under the terms and conditions of the Creative Commons Attribution (CC-BY) license (http://creativecommons.org/licenses/by/4.0/). 